\title{
Use of the Internet and its Impact on Productivity and Sales Growth in Female-Owned Firms: Evidence from India
}

\author{
Aparna Gosavi ${ }^{1}$
}

\begin{abstract}
The Internet has completely transformed our lives on an individual basis in many ways, ranging from the way we communicate through the way we socialize to the way we shop and travel. Businesses are no exception to this premise. This paper studies the adoption of the Internet by female-owned firms in India. It uses the World Bank's Enterprise Surveys Program data set for the year 2014 to study the adoption of the Internet by more than 10,000 firms in the country. After controlling for a large number of firm-level characteristics, empirical results obtained indicate that femaleowned firms are more likely to use the Internet than their male counterparts. However, further empirical analysis shows that more intensive adoption of the Internet by these female-owned firms does not necessarily translate into better performance. Specifically, the adoption of the Internet does not make female-owned firms more or less likely to have better productivity and sales growth in contrast to that of their male counterparts.
\end{abstract}

Keywords: internet; female-owned firms; productivity; sales growth; India.

\section{INTRODUCTION}

Telecom services in general and broadband Internet services in particular have changed our lives in many ways, ranging from the way we communicate, socialize, plan vacations, and do our shopping. These services are oftentimes considered to be general-purpose technologies because they benefit all the participants in the economy and exhibit persistent gains to individuals and businesses alike (Susanto Basu \& Fernald, 2007). These services are treated

1 Aparna Gosavi, B.Sc., MBA, MS, Ph.D. Assistant Professor of Finance, Winston-Salem State University, University of North Carolina System, 601 S MLK Jr. Drive Winston-Salem, North Carolina 27110, (336)750-2716, USA, e-mail: gosaviaa@ wssu.edu. 
as general-purpose technologies for a variety of additional reasons. Firstly, good quality telecom and broadband services facilitate firms to devote less time on communications and to acquire inputs more efficiently than otherwise (Röller \& Waverman, 2001). Secondly, sound and modern telecom and Internet-services infrastructures allow firms to reach large geographical areas, thereby granting them access to large markets while at the same time drastically reducing the cost of collecting information on the various parties involved in business processes (Clarke, Qiang \& Xu, 2015). Finally, the Internet plays a critical role in boosting the market share of firms, improving operations and enhancing competitive advantage (Porter, 2001; Teo \& Pian, 2003).

In particular, the impact of the adoption of the Internet has revolutionized the way businesses carry out their operations on a day-to-day basis. Nowadays, businesses have websites that contain information about their products, promotions, employees, customers' reviews and even financial statements (for public companies). The Internet has truly revolutionized and expanded horizons of business operations in many respects. One classic example of such a business is the giant on-line retailer Amazon. It maintains a list of its customers and their preferences, and keeps its customers in the loop on various promotions and new features related to their preferred products. This particular process has not only led to enhanced customer satisfaction and repeat business, but has also resulted in better quality of products.

It is not a surprise thus that the Internet has been identified as the fastest growing market place around the globe. According to the Internet World Stats (2016), there are more than 3.67 billion Internet users around the world, while the population of the world is 7.3 billion. Although the Internet is used widely around the globe, its access is unequal across countries, thereby making some countries more competitive than others. For example, in 2016, the rate of penetration (as a percentage of population) is 92 percent in the U.S. whereas the same number is 32 percent in a developing country like India, which is the country under study for this paper (The World Bank, 2016). These wide differences in the rate of penetration of the Internet put countries like India at a significant disadvantage.

Thus, if the Internet is a general-purpose technology and offers so many advantages to businesses, it is worth studying its adoption by firms in a developing country such as India. In particular, as more and more women join the work force, analyzing the adoption of the Internet by female-owned firms is an interesting and important research question. This paper analyzes the adoption of Internet services by female-owned firms, vis-à-vis their male counterparts in India. For this analysis, the paper uses an extensive firm-level data set (10,000 plus observations) from the World Bank's Enterprise Surveys for the year 2014 (The World Bank, 2014). This paper finds empirical evidence 
indicating that female-owned firms are more likely to use the Internet to communicate with their clients and they are more likely to have websites for their businesses than male-owned firms! Hence, the paper further analyses whether adoption of the Internet delivers, as a general-purpose technology, in terms of increased sales growth and productivity. The empirical analysis shows however that although female-owned firms have adopted the Internet more extensively than their male counterparts, its usage does not get translated into higher sales growth and/or productivity.

There are various reasons for the above-mentioned outcomes. In India, almost one third of the population has access to the Internet. Thus, for example, even though businesses have Internet connections, their customers may not necessarily have the same. This makes it very hard for businesses to extract opinions and preferences of their customers and also to keep track of their buying behavior - a process that can lead to customer loyalty and even better products. For example, in the US, where the Internet penetration rate is 92 percent, the digital-social-media giant Facebook maintains records of likeand-dislike posts of its users related to various products. Facebook shares this data with its business customers. In turn, Facebook users continuously get information about promotions and new features of their preferred products. This process can not only lead to repeat purchases, but can also enhance customer loyalty. Another potential reason for the empirical results in the paper could be the fact that a major part of the economy in India constitutes an informal economy. Thus, for the most part, financial transactions take a form of cash-based transactions. Customers rarely use checks or plastic money to pay or receive bills. This makes it very hard for goods and services providers to keep a record and a track of preferences of their customers and suppliers. Thus, even though businesses have the Internet presence, it does not necessarily get transmitted into better performance of these firms.

Contributions of this paper are threefold: 1 . This is the first paper that studies the usage of the Internet by female-owned firms, vis-à-vis their male counterparts in India. 2. It investigates productivity and sales growth of female-owned firms that have Internet connections. And 3. It uses a firmlevel data set of more than 10,000 firm-level observations from all sectors of the economy for the year 2014, making the study current and a near-perfect representation of the economy as a whole.

The rest of the paper is organized as follows. Section 2 discusses the existing literature, identifies the literature gap, and specifies contributions of the paper. The next section offers an empirical framework that includes a discussion on the data set and the associated empirical models. Section 4 presents the results, and the last section concludes the paper with a discussion on future avenues for research. 


\section{LITERATURE REVIEW}

Before we discuss the extant literature on the adoption of the Internet by businesses, we would like to provide an overview of the current state of the Indian economy and how they got there. This discussion is important for a couple of reasons: 1. An overview of the Indian economy presents us with an outlook of its overall economic health that has some bearing on Internet adoption and 2. A study of the path adopted by the country, which traveled from an underdeveloped-socialist country to a developing-mixed-economy country, helps us understand various policy decisions made on the way and their impact on the adoption of this modern technology, namely, the Internet.

India, which is a lower-middle-income country, is the second most populous country in the world with a little over two trillion dollars' worth of GDP (The World Bank, 2016). If we look at the quality of the work force in terms of education, more than 70 percent of the people in the country are literate. However, only 24 percent of the people in the country are enrolled in a tertiary education system. Further, the majority of the structure of employment shows that the services sector contributes 53 percent to its GDP, the manufacturing sector contributes 17 percent, and 20 percent is contributed by the farming sector (see Figure 1 ). There has been a steady growth in the services sector and a steady decline in the agricultural sector since 1991, which is a clear sign that the economy is becoming a consumerbased economy; the latter is a potential sign of economic development.
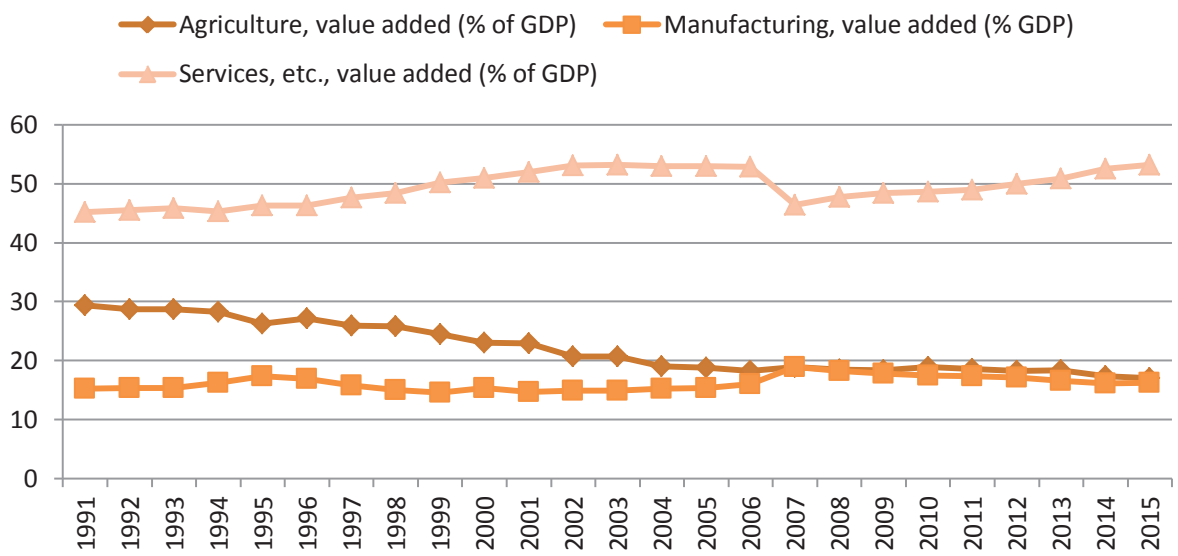

Figure 1. Agriculture, Manufacturing and services Sectors as \% of GDP Source: The World Bank's World Development Indicators (2016). 
At the same time, the employment structure of males and females in three sectors - agriculture, services and industry-echoes matching numbers as that of the contributions to the GDP by the same three sectors (see Table 1). Fewer workers were employed in the agricultural sector in 2012 than in 1994. This declining trend of employment in the agricultural sector is almost going hand in hand for males and females. Further, the economy experienced substantial growth of employment in the services and the industrial sector, which is a positive sign for the economy because it indicates that the economy is moving away from the agricultural based economy.

Table 1. Employment structure of males and females in the economy

\begin{tabular}{|c|c|c|c|c|c|c|}
\hline$\stackrel{\text { ঠ }}{\nu}$ & 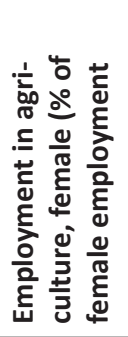 & 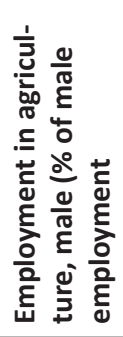 & 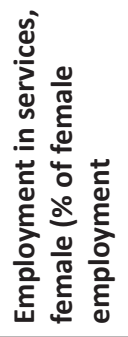 & 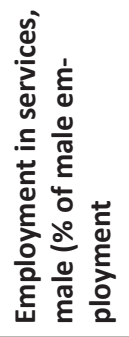 & 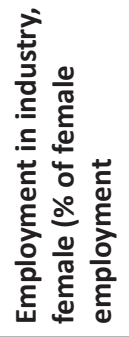 & 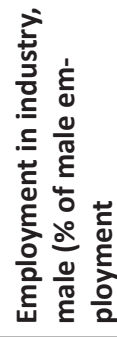 \\
\hline 1994 & 72.4 & 55.7 & 12.5 & 25.9 & 12.4 & 17.1 \\
\hline 2000 & 74.8 & 53.9 & 13.7 & 28.2 & 11.5 & 17.9 \\
\hline 2005 & 70.9 & 49.2 & 14.7 & 29.8 & 14.4 & 21.0 \\
\hline 2010 & 65.3 & 46.0 & 17.0 & 29.9 & 17.8 & 24.0 \\
\hline 2012 & 59.7 & 42.9 & 19.4 & 31.0 & 20.9 & 26.1 \\
\hline
\end{tabular}

Source: The World Bank's World Development Indicators (2016).

These transitions from a farmed-sector-based economy to a servicessector-based economy, in terms of contributions to the GDP as well as employment structures, have carved out a long journey. In 1991, the Indian Government liberalized its economy by boosting the growth of trade and by reducing regulations on businesses. These reforms have three dimensions: the industrial policy, the trade policy, and the financial sector policy. Under the industrial policy, the government has undertaken massive deregulation of the industrial sector by reducing and/or dismantling regulations and cancelling the so-called "license raj." Until 1991, there were eighteen industrial sectors solely reserved for the public sector; under the reforms that number was brought down to three. Most importantly, restrictions on the import of foreign technology were removed. Under the reforms in the trade policy, tariffs on imports were reduced and other import restrictions were removed. 
Under the reforms in the financial sector, the Indian currency became freely floated and interest rates were liberalized. Because of the confluence of all these above-described reforms, the economy has experienced more than 6 percent growth since 1991, which still continues to date. At the same time, the country has been experiencing a solid growth in the usage of Internet services (see Table 2 and Figure 2). In 2016, 15 percent of the households had a computer and were spending $\$ 5$ per month (which is a significant sum of money in terms of the Indian currency) for a fixed-broadband internet connection (The World Bank, 2016). Finally, the GDP growth rate and the volume of ICT goods imported and imported exhibit similar trends (see Figure 2).

Table 2. Secure internet servers and their density

\begin{tabular}{llll}
\hline Year & $\begin{array}{l}\text { Secure Internet } \\
\text { Servers }\end{array}$ & $\begin{array}{l}\text { Secure Internet Servers } \\
\text { (per 1 million people) }\end{array}$ & $\begin{array}{l}\text { Internet users } \\
\text { (per 100 people) }\end{array}$ \\
\hline 2001 & 122 & 0.1138 & 0.6601 \\
2002 & Not aaailable & Not available & 1.5378 \\
2003 & 281 & 0.2535 & 1.6864 \\
2004 & 462 & 0.4101 & 1.9761 \\
2005 & 658 & 0.5750 & 2.3880 \\
2006 & 825 & 0.7099 & 2.8054 \\
2007 & 1121 & 0.9502 & 3.95 \\
2008 & 1462 & 1.2213 & 4.38 \\
2009 & 1796 & 1.4791 & 5.12 \\
2010 & 2601 & 2.1129 & 7.5 \\
2011 & 3545 & 2.8418 & 10.07 \\
2012 & 4412 & 3.4916 & 12.58 \\
2013 & 4889 & 3.8210 & 15.1 \\
2014 & 7173 & 5.5377 & 21.0 \\
2015 & 8944 & 6.8220 & 26.0 \\
\hline
\end{tabular}

Source: The World Bank's World Development Indicators (2016).

Some studies establish a theoretical link between the adoption of generalpurpose technologies and its benefits to businesses as well as the economy at large. Bersnahan and Trajtenberg (1995) propose and test the idea of whether general-purpose technologies are engines of economic growth. Back in the mid-1990s, when their article was written, general-purpose technologies were steam engines, electric motors, and semiconductors. Although, nowadays, general-purpose technologies exist in the form of information and communication technologies, a theoretical framework proposed by 
Bersnahan and Trajtenberg (1995) is still applicable to the present. They show a theoretical link between general-purpose technologies and a boost to 'return-to-scale.' S. Basu and Fernald (2008) theoretically prove that the adoption of the new communication technologies lead to an increase in labor productivity. They also test their theoretical framework by using U.S. industry data and find that an increase in investments for information technologies lead to higher labor productivity, but with a long lag.

Now, we will turn our attention to the extant literature on the adoption of the Internet by businesses. Early studies, which were primarily focused on developed countries, on the adoption of the Internet by small and mediumsized businesses focus on various factors that were affecting the adoption of the Internet. For example, for businesses in Australia, Poon and Swatman (1997) find that firms use this service as a mode of communications and not so much for transferring documents or for advertising products and services. In another study of small and medium-sized firms in the UK, Levy and Powell (2003) find that the adoption of the Internet by these firms is a function of the owners' identification of the value of the Internet for their businesses in terms of growth of the businesses. Additionally, one more study of adoption of the Internet by small firms from the Netherlands suggests that the small firms do not adopt the service at the same pace as the large firms and claims that small businesses believe that the adoption of the Internet may not lead to more efficiency (Walczuch, Van Braven \& Lundgren, 2000).

Another study on the adoption of the Internet by small firms in New Zealand indicates that perceived benefits, organizational readiness, and external pressure are the contributing factors for the usage of the service (Mehrtens, Cragg \& Mills, 2001). In the same vein, Teo, Tan, and Buk (1997) find that for firms in Singapore, "organizational and technological factors, rather than environmental factors," play a major role in the adoption of the Internet. Adam, Mulye, Deans, and Palihawadana (2002) compare the use of the Internet and Web services among three developed countries-Australia, New Zealand, and the UK. In all of these three countries, firms use the Web for marketing communications, but, usage of the Internet for transactions in terms of marketing channels is much lower. Also, UK firms are more advanced in terms of the adoption of the Internet than those in Australia. In their study on the adoption of the Internet and websites by small and mediumsized firms in the U.S. Dholakia and Kshetri (2004) find that prior technology adoption and the influence of competitors' adoption of technology have a big impact on the propensity of adopting the Internet. 


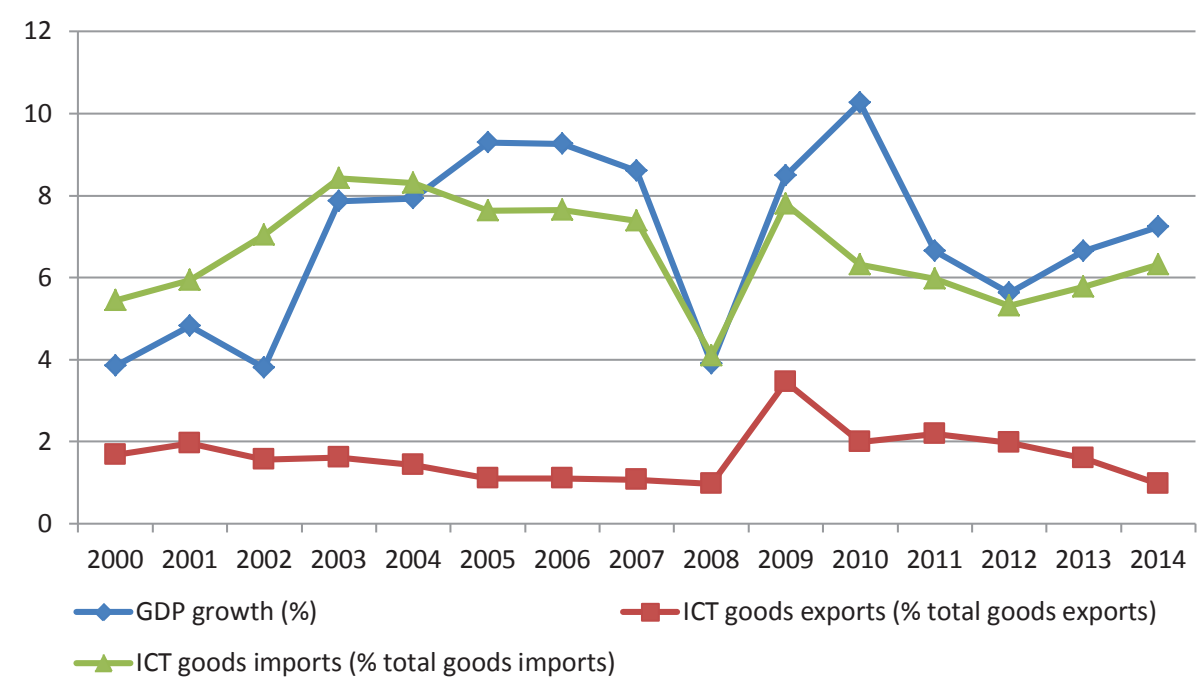

Figure 2. GDP growth rate, Information and Communication Technology (ICT) goods--imports and exports

Source: The World Bank's World Development Indicators, 2016.

Another aspect that can affect the adoption of the Internet is the societal culture in general and the organizational culture in particular that appears to have a great influence on the adoption rates of the Internet (Dasgupta, Agarwal, loannidis, \& Gopalakrishnan, 1999). Their study, which focuses on India, finds that size, competition, government policies, exchange rates, and computer prices have a significant impact on the adoption of the technology. Moreover, poverty levels also play an important role. Although poverty lines are country specific, approximately 21 percent of the population earned no more than \$1.90 per day in 2011 (The World Bank, 2016). Only a small percentage of the population can be potential users (see Table 2). Interestingly, one third of the population is well-educated and eager to adopt new technologies. These users are predominantly young, male, and belong to the middle and higher classes (Raven, Huang, \& Kim, 2009). Ironically, the best-run software companies-Infosys Ltd., Tata Communications Ltd., and Wipro-are listed on the U.S. stock market. Further, India is forecast to become the world's second-largest Internet user base after China by the end of 2016 (WSJ, 2015).

Early studies on the adoption of the Internet in developing countries also suggest that similar outcomes for businesses were found in developed countries. One study out of China claims that larger companies benefit more 
in terms of sales and reduced costs (Riquelme, 2002). In their study of small and medium-sized firms in Malaysia, Sin Tan, Choy Chong, Lin, and Cyril Eze (2010) focus on demographic characteristics of these firms. They find that service-sector firms are more likely to adopt the service than manufacturing firms and that small and medium-sized firms benefit more for the adoption than micro-sized firms.

The adoption of the Internet is also affected by various factors that surround the firms. These factors are: a regulatory environment, the infrastructure with respect to information technology, and availability of skilled employees (Shore, 1998). Although in India regulatory reforms have been undertaken since 1991, these reforms are not good enough to increase the number of businesses or for businesses to flourish. The World Bank's Doing Business statistics offers some insights on running a business in the country. India ranks $130^{\text {th }}$ (out of 190 countries) and scores 55.27 percent in terms of doing business (overall) (The World Bank, 2016a). Also, various business-related issues-such as dealing with construction permits, paying taxes, and enforcing contracts-are ranked below $170^{\text {th }}$ out of 190 countries. Thus, even though the economy opened up in the early 1990s, things do not look as promising as they should when it comes to doing business in the country. Moreover, as far as India is concerned, infrastructure in terms of information technology has a lot of potential for improvement (see Table 2). The numbers for total number of secure servers and secure Internet server density are on the rise, but frustratingly lower than developed countries, making it a major hurdle for the people and businesses to get connected on line.

Some recent studies show that challenges for the adoption of the Internet and communication technology by businesses still persist worldwide. A survey on the adoption of the technology by about 400 small and medium enterprises in Malaysia show that the level of skills of owners needed, related to the adoption of technology, is poor and that their rate of adoption of the technology is slow and delayed (Hashim, 2015). Colombo, Croce, and Grilli (2013) study the adoption of broadband Internet connections of 800 small and medium enterprises in Italy. They find that the impact of the adoption of broadband on productivity of firms is negligible or even negative. Grimes, Ren, and Stevens (2012) study the impact of the speed of the Internet on the productivity of small and medium-sized enterprises in New Zealand. They find that broadband Internet connections enhance productivity of firms. In the same vein, Bertschek (2012) study the adoption of broadband Internet connections by firms in Germany and find a positive relationship between the adoption of broadband connections and innovation activities. The same study shows a smaller impact on labor productivity, however. 
There are some studies that have studied Internet banking adoption in India (Kumar Sharma \& Madhumohan Govindaluri, 2014; Malhotra \& Singh, 2007; Roy, Kesharwani \& Singh Bisht, 2012). On the other hand, some other studies focus on cultural aspects of India and its relationship with Internet shopping (Adapa, 2008; Rangaswamy \& Cutrell, 2012). In their paper on E-Commerce, Tarafdar and Vaidya (2006) explain why firms differ in their adoption of E-Commerce. Their study finds that organizational culture, characteristics of information systems professionals, and organizational structure influence the adoption of the technology. Finally, these researchers claim that the utilization of technology has a significantly positive impact on the internationalization of small and medium firms in India. The existing literature shows that most attention is given to the adoption of the technology vis-à-vis culture and organizational structure.

Thus, a common theme emerges from the extant literature on the adoption of the Internet by small and medium-sized firms. In the late 1990s and early 2000s, a majority of these firms were slow in adopting the Internet. Also, benefits of the service in terms of increased sales and reduced costs were more tilted towards large firms than other firms. However, as time passed by and the technology became cheaper and more accessible, firms of all sizes, age groups, and sectors started adopting the Internet, thus making the service a necessity rather than a choice. Moreover, a majority of the studies on the adoption of the Internet by firms are done on developed countries (Oliveira and Martins, 2010). However, scant attention has been given to the usage of the Internet and of websites by firms in general and their adoption by female-owned firms in particular-a literature gap this paper seeks to fill. This study is necessary because the number of females as a part of the workforce is on the rise (see Table 1), thus, making it meaningful and necessary to investigate Internet adoption by female-owned firms.

Contributions of this paper are threefold: 1. To the best of my knowledge, this is the first paper that studies the adoption of the Internet by female-owned firms. 2. The paper investigates productivity and sales growth of female-owned firms that have Internet connections. And 3. The paper uses a firm-level data set from the World Bank of more than 10,000 firm-level observations from all sectors of the economy for the year 2014, making the study current and a near-perfect representation of the economy as a whole. 


\section{RESEARCH METHODS}

The paper uses the World Bank's enterprise Surveys data set for the year 2014. The data set consists of more than 10,000 firm-level observations. In the data set a particular question was asked about the adoption of the Internet by the firms. The Surveys specifically asked questions regarding the adoption of the Internet. These questions were: 1 . Does the firm have a high-speed Internet connection on its premises? 2. Does the establishment have its own website? And 3 . Do you currently communicate with clients and suppliers by emails? The paper uses these specific questions to study Internet adoption. The key independent variable (Model 1 ) is a dummy variable that takes the form of " 1 " if the firms have access to the Internet and use the service to communicate with their clients and suppliers by emails, and the dummy variable takes the form of " 0 " otherwise. Also, the paper uses the same model to study whether firms have their own websites. Thus, an independent variable takes the form of " 1 " if the firms have their own websites and is zero otherwise.

\section{Measuring female-owned firms}

The dependent variable is whether the firm is owned and managed by females (Model 1). The data set provides specific information on the structure of ownership of firms. This variable is based on a question from the Surveys. The Surveys specifically asked a question that "amongst the owners of the firm, are there any females?" The Surveys also asked a question whether firms have top managers as females. The paper uses these two questions together to form a variable that the firms is owned and managed by females. Answers to these questions may not correctly reveal the information regarding the number of female owners or percentage of ownership by females in the firms. Nevertheless, the answers to these questions provide information about the female ownership with certainty. In many studies, which use Enterprise Surveys data sets, a firm is considered to be female owned if at least one of the owners is a female (Aterido, Beck \& lacovone, 2011; Bardasi, Sabarwal \& Terrell, 2011; Hansen \& Rand, 2014).

Further, it is important to put together the above-mentioned two questions about the role of females in the firms because oftentimes firms that are owned by females are not necessarily managed by them. One important aspect of female-owned firms is the decision-making authority of their own businesses. Generally, husbands or male partners or male siblings, who may not be fully involved in day-to-day business operations, of these female-business owners make decisions that can have a long-lasting impact on operations and outcomes of businesses. One study suggests that firms 
in which females have a part ownership, men make decisions in 77 percent of the business operations-a significantly high number making it critical to pay a closer look at decision-makers and not only at ownership (Aterido \& Hallward-Driemeier, 2011). Thus, this decision making role played by minor male stakeholders or male non-owners affects the performance of these firms. Further, the information is available regarding whether top managers of firms are females. Thus, by using the same model (Model 1), analysis is performed for firms where top managers are females.

Once we know whether female-owned firms use the Internet and websites for their businesses, the next step in the investigation is to find out whether this adoption helps firms to enhance their performance (Clarke et al., 2015). To be specific, the performance is measured in terms of sales growth and labor product (Model 2). In this particular model, the key independent variable is the interaction term of firms owned and managed by females and adoption of the Internet by these firms. Additionally, the model controls for various firm-level characteristics to reduce selection bias.

Both empirical models use various firm-level characteristics as control variables in order to reduce the selection bias in these models. In particular, the models control for age, size, sector, export-oriented status of the firms, and access to finance. These controls are constructed as follows: For the control variable, age, there are three strata. The firms with age of less than 5 years are identified as young firms, the firms with age between 5 and 10 years old are termed as medium-aged firms and firms that have age in between 10 and 99 are viewed as old firms. As far as a size of the firms is concerned, firms with up to 19 employees are treated as small firms, firms that have employees in between 20 and 99 are treated as medium-sized firms, and firms that have more than 100 employees are treated as large firms (see Tables 3 and 4).

Table 3. Percentage of firms that are owned and managed by males and females vis-à-vis firms' characteristics

\begin{tabular}{lll}
\hline Firm Characteristics & $\begin{array}{l}\text { Firms that are owned } \\
\text { and managed my } \\
\text { females } \\
\text { that use the technology } \\
\text { (in \%) }\end{array}$ & $\begin{array}{l}\text { Firms that are } \\
\text { owned and } \\
\text { managed by } \\
\text { males that use the } \\
\text { technology (in \%) }\end{array}$ \\
\hline $\begin{array}{l}\text { Company that uses email/web to } \\
\text { communicate with clients (dmintuse) } \\
\begin{array}{l}\text { Internet company either uses web to } \\
\text { communicate with clients (dmintweb) }\end{array}\end{array}$ & 95.32 & 86 \\
$\begin{array}{l}\text { Internet - Company either uses e-mail to } \\
\text { communicate with clients }\end{array}$ & 95 & 48 \\
\hline
\end{tabular}




\begin{tabular}{lll}
\hline Firm Characteristics & $\begin{array}{l}\text { Firms that are owned } \\
\text { and managed my } \\
\text { females } \\
\text { that use the technology } \\
\text { (in \%) }\end{array}$ & $\begin{array}{l}\text { Firms that are } \\
\text { owned and } \\
\text { managed by } \\
\text { males that use the } \\
\text { technology (in \%) }\end{array}$ \\
\hline Age up to 5 years & 6 & 7 \\
Age 5-10 years & 84 & 80 \\
Age 10 to 99 years & 79 & 74 \\
Export-oriented status & 37 & 15 \\
Manufacturing-sector firms & 74 & 22 \\
Retail-sector firms & 10 & 9 \\
Services-sector firms & 17 & 13 \\
\hline
\end{tabular}

Source: based on author's calculations of the Enterprise Surveys (2014).

Table 4. Percentage of firms that are owned and managed by males and females vis-à-vis firms' characteristics

\begin{tabular}{lll}
\hline Firm Characteristics & $\begin{array}{l}\text { Firms where top } \\
\text { managers are females } \\
\text { and use the technology } \\
\text { (in \%) }\end{array}$ & $\begin{array}{l}\text { Firms where top } \\
\text { managers are } \\
\text { males and use the } \\
\text { technology (in \%) }\end{array}$ \\
\hline $\begin{array}{l}\text { Company that uses email/web to } \\
\text { communicate with clients (dmintuse) }\end{array}$ & 95 & 85 \\
$\begin{array}{l}\text { Internet company either uses web to } \\
\text { communicate with clients (dmintweb) }\end{array}$ & 79 & 51 \\
$\begin{array}{l}\text { Internet - Company either uses e-mail } \\
\text { to communicate with clients }\end{array}$ & 95 & 84 \\
Age up to 5 years & 6 & 7 \\
Age 5-10 years & 19 & 19 \\
Age 10 to 99 years & 75 & 74 \\
Export-oriented status & 30 & 14 \\
Manufacturing-sector firms & 68 & 78 \\
Retail-sector firms & 10 & 9 \\
Services-sector firms & 22 & 13 \\
\hline
\end{tabular}

Source: based on author's calculations of the Enterprise Surveys (2014).

The data set offers extensive information about the sector to which these firms belong. In the model, three sectors are considered-manufacturing, retail and services. This sector classification is based on the primary products or services that the firms offer. This particular classification of the sector represents all the sectors in the economy, thus making the analysis a nearperfect representation of the economy as a whole. Further, the Surveys also have a question on whether the products are exported. Thus, the models 
control for the export-oriented status of the firms to find out whether these firms are more adaptive to Internet services.

Finally, the models control for the access-to-finance status of the firms. This control is very important for two reasons: 1 . It tells us whether firms are creditworthy and 2. If yes, it sends a signal that these firms have future profitable projects that can be totally funded by reserves and surplus, and that is why they need finance. This control variable is constructed as follows. It makes use of the question: "How much of an obstacle access to finance is." Five choices are given to the respondents to choose from: no obstacle, minor obstacle, moderate obstacle, major obstacle, and a very severe obstacle. In the variable, no obstacle takes a value of 1 . The responses for minor obstacles and moderate obstacles are combined and take a value of $\mathbf{2}$. Finally, the responses for major obstacles and very severe obstacles are combined and take a value of $\mathbf{3}$. Thus, the coefficient on this variable is interpreted as follows: if a regression coefficient is positive on this variable, an increase in this variable will increase the likelihood that the firms will have major or very severe obstacles in accessing credit.

\section{Model 1:}

$$
y_{i}=\beta_{0}+\beta_{1} \text { Internet }_{i}+\mathrm{FLC}_{i}+\mu_{i}
$$

where the subscript " $i$ " represents a firm in the country.

The dependent variable above is firms owned and managed by females or firms where top managers are females. The key independent variable is the adoption of the Internet or the usage of websites by firms. The model controls for various firm-level controls ( such as age, size, sector, exportoriented status, and access to finance.

\section{Model 2:}

$$
\text { Performance of firms }{ }_{i}=\alpha_{0}+\alpha_{1} x_{i}+F L C_{i}+\mu_{i}
$$

where the subscript " $\mathrm{i}$ " represents a firm in the country.

The key independent variable is an interaction term of firms owned and managed by females and firms that use the Internet. The dependent variable is performance of the firms measured in terms of sales growth and labor productivity. The same model (Model 2) is subsequently used where 
the key independent variable, is now an interaction term of firms in which top managers are females and firms that use the Internet.

To compute sales growth and labor productivity, a method used in Clarke et al. (2015) is employed, which can be explained as follows. In order to compute sales growth, Enterprise Surveys data from the years 2010 and 2014, which form a panel data set, are employed. The Surveys specifically asks a question on sales revenues. The year 2010 is utilized as a base year. In order to compute sales growth, sales revenue numbers from 2010 and 2014 are employed. To make these two numbers comparable, GDP deflators for both years are used. In order to compute labor productivity, real sales for the year 2014 (using GDP deflator for 2014) are used. These real sales are divided by the number of full-time permanent workers to compute labor productivity. The model uses standard firm-level controls-age, size, sector, export-oriented status, and access-to-finance-to reduce any selection bias.

\section{ANALYSIS AND EMPIRICAL RESULTS}

Empirical analysis shows that firms that are owned and managed by females are more likely to use the Internet and websites for their businesses than their male counterparts (Model 1, see Table 5: Columns 1 and 3). Also, firms in which top managers are females are more likely to use the Internet and websites for their businesses than their male counterparts (Model 1, see Table 5: Columns 2 and 4). Thus, overall, these results clearly indicate that Indian firms owned and run by females, in comparison to those owned and run my males, have a higher propensity towards the use of the Internet.

Firm-level control variables show the expected signs for their regression coefficients. Thus, firms where top managers are females and are medium in size are more likely to use the Internet and websites in comparison to small firms where top managers are female. Also, the same results are obtained when large firms are compared to small firms. This indicates that the size of the firms matters when it comes to adoption of the Internet-the larger the firm, the more likely it is to have a propensity towards the use of the Internet. In addition, firms that are involved in export activities are more likely to use both-the Internet and websites. Interestingly, as far as sectors in the economy and firms where top managers are females are concerned, manufacturing-sector firms are less likely to use the technology than servicessector firms. However, being in the retail sector does not make firms more or less likely to use the technology than being in the services sector. Finally, the access-to-finance variable is only statistically significant for firms where top managers are females. This clearly shows that access to finance is a vexing problem when firms are solely managed and run by females. 
Table 5. Empirical results of Model 1

\begin{tabular}{lllll}
\hline $\begin{array}{l}\text { Measurement of } \\
\text { adoption of the Internet } \\
\text { and Websites }\end{array}$ & $\begin{array}{l}\text { Firms that are } \\
\text { owned and } \\
\text { managed by } \\
\text { females } \\
\text { Column 1 }\end{array}$ & $\begin{array}{l}\text { Firms } \\
\text { where top } \\
\text { managers } \\
\text { are females } \\
\text { Column 2 }\end{array}$ & $\begin{array}{l}\text { Firms that are } \\
\text { owned and } \\
\text { managed by } \\
\text { females } \\
\text { Column 3 }\end{array}$ & $\begin{array}{l}\text { Firms } \\
\text { where top } \\
\text { managers } \\
\text { are females } \\
\text { Column 4 }\end{array}$ \\
\hline $\begin{array}{l}\text { Use of the Internet for } \\
\text { communicating with } \\
\text { customers and suppliers }\end{array}$ & $\begin{array}{l}0.333 \\
(3.03)^{* *}\end{array}$ & $\begin{array}{l}0.378 \\
(4.76)^{* *}\end{array}$ & & \\
\hline Use of websites & -- & -- & $\begin{array}{l}0.275 \\
(4.26)^{* *}\end{array}$ & 0.403 \\
& & & & $(8.38)^{* *}$ \\
\hline
\end{tabular}

Firm age [dummy, the omitted age is up to 5 years]

\begin{tabular}{lllll}
\hline Medium-aged (5 to 10 & -0.033 & 0.057 & -0.039 & 0.052 \\
years) & $(0.26)$ & $(0.61)$ & $(0.30)$ & $(0.55)$ \\
\hline Old-aged (10 to 99 years) & 0.058 & 0.044 & 0.059 & 0.055 \\
& $(0.51)$ & $(0.52)$ & $(0.52)$ & $(0.64)$ \\
\hline
\end{tabular}

Firm size [dummy, the omitted size is small firms (5 to 19 workers)]

\begin{tabular}{lllll}
\hline Firm size: medium (20 to & -0.041 & 0.164 & -0.058 & 0.119 \\
99 workers) & $(0.59)$ & $(3.14)^{* *}$ & $(0.83)$ & $(2.25)^{*}$ \\
\hline Firm size: large (more & 0.270 & 0.454 & 0.210 & 0.346 \\
than 100 workers) & $(3.70)^{* *}$ & $(8.00)^{* *}$ & $(2.75)^{* *}$ & $(5.86)^{* *}$ \\
\hline Export [dummy] & 0.452 & 0.369 & 0.410 & 0.303 \\
& $(7.17)^{* *}$ & $(7.38)^{* *}$ & $(6.39)^{* *}$ & $(5.97)^{* *}$ \\
\hline
\end{tabular}

\begin{tabular}{lllll}
\hline $\begin{array}{l}\text { Sector type [dummy, the } \\
\text { omitted sector is services } \\
\text { sector] }\end{array}$ & & & & \\
\hline Sector type: & -0.189 & -0.382 & -0.144 & -0.314 \\
manufacturing & $(2.56)^{*}$ & $(7.24)^{* *}$ & $(1.93)$ & $(5.86)^{* *}$ \\
\hline Sector type: retail & 0.045 & -0.080 & 0.071 & -0.034 \\
& $(0.41)$ & $(1.01)$ & $(0.65)$ & $(0.43)$ \\
\hline Access to finance status & 0.007 & 0.104 & 0.007 & 0.110 \\
[dummy] & $(0.17)$ & $(3.49)^{* *}$ & $(0.17)$ & $(3.64)^{* *}$ \\
\hline cons & -2.235 & -1.983 & -2.106 & -1.903 \\
& $(12.52)^{* *}$ & $(15.10)^{* *}$ & $(13.52)^{* *}$ & $(16.34)^{* *}$ \\
\hline $\mathrm{N}$ & 9,138 & 9,194 & 9,131 & 9,187 \\
\hline
\end{tabular}

Notes: Dependent variable: 1 . Firms that are owned and managed by females (columns 1 and 3); 2. Firms where top managers are females (columns 2 and 4); t-statistics are in parentheses. $* * *, * *, *$ are statistically significant at 1,5 , and 10 percent significance levels respectively. Source: based on author's calculations of the Enterprise Surveys (2014) 
Table 6. Empirical results of Model 2

\begin{tabular}{|c|c|c|}
\hline $\begin{array}{l}\text { Measurement of performance of female- } \\
\text { owned firms AND their adoption of the } \\
\text { Internet }\end{array}$ & $\begin{array}{l}\text { Sales growth } \\
\text { Column } 1\end{array}$ & $\begin{array}{l}\text { Labor productivity } \\
\text { Column } 2\end{array}$ \\
\hline $\begin{array}{l}\text { Firms that are owned and managed } \\
\text { by females AND use the Internet for } \\
\text { communications with customers and } \\
\text { suppliers }\end{array}$ & $\begin{array}{l}0.743 \\
(0.29)\end{array}$ & $\begin{array}{l}0.216 \\
(1.48)\end{array}$ \\
\hline $\begin{array}{l}\text { Firms that are owned and managed by } \\
\text { females }\end{array}$ & $\begin{array}{l}0.101 \\
(0.04)\end{array}$ & $\begin{array}{l}-0.132 \\
(0.93)\end{array}$ \\
\hline $\begin{array}{l}\text { Firms that use the Internet for } \\
\text { communications with customers and } \\
\text { suppliers }\end{array}$ & $\begin{array}{l}0.449 \\
(1.61)\end{array}$ & $\begin{array}{l}0.154 \\
(9.11)^{* *}\end{array}$ \\
\hline \multicolumn{3}{|l|}{$\begin{array}{l}\text { Firm age [dummy, the omitted age is up to } \\
5 \text { years] }\end{array}$} \\
\hline Medium-aged (5 to 10 years) & $\begin{array}{l}-2.045 \\
(4.12)^{* *}\end{array}$ & $\begin{array}{l}0.040 \\
(1.61)\end{array}$ \\
\hline Old-aged (10 to 99 years) & $\begin{array}{l}-3.540 \\
(7.64)^{* *}\end{array}$ & $\begin{array}{l}0.064 \\
(2.85)^{* *}\end{array}$ \\
\hline \multicolumn{3}{|l|}{$\begin{array}{l}\text { Firm size [dummy, the omitted size is small } \\
\text { firms ( } 5 \text { to } 19 \text { workers)] }\end{array}$} \\
\hline Firm size: medium (20 to 99 workers) & $\begin{array}{l}0.570 \\
(2.60)^{* *}\end{array}$ & $\begin{array}{l}1.249 \\
(94.57)^{* *}\end{array}$ \\
\hline Firm size: large (more than 100 workers) & $\begin{array}{l}0.523 \\
(1.96)^{*}\end{array}$ & $\begin{array}{l}3.037 \\
(188.40)^{* *}\end{array}$ \\
\hline \multicolumn{3}{|l|}{$\begin{array}{l}\text { Sector type [dummy, the omitted sector is } \\
\text { services sector] }\end{array}$} \\
\hline Sector type: manufacturing & $\begin{array}{l}0.206 \\
(0.74)\end{array}$ & $\begin{array}{l}-0.043 \\
(2.61)^{* *}\end{array}$ \\
\hline Sector type: retail & $\begin{array}{l}1.361 \\
(3.36)^{* *}\end{array}$ & $\begin{array}{l}-0.260 \\
(10.89)^{* *}\end{array}$ \\
\hline Export [dummy] & $\begin{array}{l}0.422 \\
(1.58)\end{array}$ & $\begin{array}{l}0.189 \\
(11.69)^{* *}\end{array}$ \\
\hline Access to finance status [dummy] & $\begin{array}{l}0.054 \\
(0.40) \\
\end{array}$ & $\begin{array}{l}-0.045 \\
(5.46)^{* *}\end{array}$ \\
\hline $\mathrm{R} 2$ & 0.02 & 0.83 \\
\hline $\mathrm{N}$ & 8,225 & 9,138 \\
\hline
\end{tabular}

Notes: Dependent variable: 1. Sales growth of firms (columns 1); 2. Labor productivity of firms (column 2 ); t-statistics are in parentheses. ${ }^{* * *}, * *, *$ are statistically significant at 1,5 , and 10 percent significance levels respectively.

Source: based on author's calculations of the Enterprise Surveys (2014). 
172 / Use of the Internet and its Impact on Productivity and Sales Growth in Female-Owned Firms: Evidence from India

Table 7. Empirical results of Model 2

\begin{tabular}{|c|c|c|}
\hline $\begin{array}{l}\text { Performance of firms where top } \\
\text { managers are females AND their } \\
\text { adoption of the Internet }\end{array}$ & $\begin{array}{l}\text { Sales growth } \\
\text { Column } 1\end{array}$ & $\begin{array}{l}\text { Labor productivity } \\
\text { Column } 2\end{array}$ \\
\hline $\begin{array}{l}\text { Firms where top managers are females } \\
\text { AND use the Internet for communications } \\
\text { with customers and suppliers }\end{array}$ & $\begin{array}{l}0.787 \\
(0.50)\end{array}$ & $\begin{array}{l}0.095 \\
(1.01)\end{array}$ \\
\hline Firms where top managers are females & $\begin{array}{l}-0.194 \\
(0.13)\end{array}$ & $\begin{array}{l}-0.004 \\
(0.05)\end{array}$ \\
\hline $\begin{array}{l}\text { Firms that use the Internet for } \\
\text { communications with customers and } \\
\text { suppliers }\end{array}$ & $\begin{array}{l}0.432 \\
(1.53)\end{array}$ & $\begin{array}{l}0.153 \\
(8.98)^{* *}\end{array}$ \\
\hline \multicolumn{3}{|l|}{$\begin{array}{l}\text { Firm age [dummy, the omitted age is up to } \\
5 \text { years] }\end{array}$} \\
\hline Medium-aged (5 to 10 years) & $\begin{array}{l}-2.095 \\
(4.23)^{* *}\end{array}$ & $\begin{array}{l}0.038 \\
(1.54)\end{array}$ \\
\hline Old-aged (10 to 99 years) & $\begin{array}{l}-3.563 \\
(7.70)^{* *}\end{array}$ & $\begin{array}{l}0.065 \\
(2.89)^{* *}\end{array}$ \\
\hline \multicolumn{3}{|l|}{$\begin{array}{l}\text { Firm size [dummy, the omitted size is small } \\
\text { firms ( } 5 \text { to } 19 \text { workers)] }\end{array}$} \\
\hline Firm size: medium (20 to 99 workers) & $\begin{array}{l}0.548 \\
(2.50)^{*}\end{array}$ & $\begin{array}{l}1.248 \\
(94.71)))\end{array}$ \\
\hline Firm size: large (more than 100 workers) & $\begin{array}{l}0.449 \\
(1.68)\end{array}$ & $\begin{array}{l}3.033 \\
(188.33)^{* *}\end{array}$ \\
\hline \multicolumn{3}{|l|}{$\begin{array}{l}\text { Sector type [dummy, the omitted sector is } \\
\text { services sector] }\end{array}$} \\
\hline Sector type: manufacturing & $\begin{array}{l}0.233 \\
(0.84)\end{array}$ & $\begin{array}{l}-0.037 \\
(2.26)^{*}\end{array}$ \\
\hline Sector type: retail & $\begin{array}{l}1.387 \\
(3.43)^{* *}\end{array}$ & $\begin{array}{l}-0.253 \\
(10.67)^{* *}\end{array}$ \\
\hline Export [dummy] & $\begin{array}{l}0.450 \\
(1.69)\end{array}$ & $\begin{array}{l}0.188 \\
(11.69)^{* *}\end{array}$ \\
\hline Access to finance status [dummy] & $\begin{array}{l}0.036 \\
(0.27)\end{array}$ & $\begin{array}{l}-0.046 \\
(5.60)^{* *}\end{array}$ \\
\hline $\mathrm{R} 2$ & 0.01 & 0.83 \\
\hline $\mathrm{N}$ & 8,256 & 9,194 \\
\hline
\end{tabular}

Notes: Dependent variable: 1 . Sales growth of firms (columns 1 ); 2 . Labor productivity of firms (column 2 ); t-statistics are in parentheses. ${ }^{* * *},{ }^{* *},{ }^{*}$ are statistically significant at 1,5 , and 10 percent significance levels respectively.

Source: based on author's calculations of the Enterprise Surveys (2014). 
Further, it is essential to analyze whether adoption of the Internet for communications and the usage of websites by female-owned firms make them more productive than their male counterparts. To study this relationship, the paper analyses this issue by measuring performance in terms of sales growth and labor productivity (Model 2). In this analysis, the key independent variable is the interaction term of firms owned plus managed by females and adoption of the Internet by these firms (Model 2 , see Table 6). Again, Model 2 is used for firms where top managers are females (Model 2, see Table 7). The empirical results show that adoption of the Internet by these firms does not make them more or less likely to have more sales or improved labor productivity. As expected, firms that use the Internet exhibit higher labor productivity than others (see Tables 6, 7 and Column 2). However, when the variable $x_{i}$, which indicated whether the firm is owned and managed by females and where top manager are females, is introduced into the model, the regression coefficients become statistically insignificant. This certainly indicates that adoption of the Internet in itself does lead to higher productivity; however, it disappears when the firms are owned and/or are run by females. Further, as a robustness check, tests were performed to determine whether the adoption of websites by these firms results in higher sales and labor productivity than their male counterparts. The results of this check also show that the usage of websites does not make these firms more or less likely to make them perform better than other firms.

\section{CONCLUSION}

Technology, in terms of usage of the Internet, plays a critical role in the development of any country, and India is no exception to this premise. Therefore, the adoption of the Internet by firms in general and by femaleowned firms in particular, is a topic that took center stage in this paper. In order to study this phenomenon, the paper used the World Bank's Enterprise Surveys Program data set. The data set had more than 10,000 firms-level observations, which allowed studying the firms in various dimensions. The paper found out that female-owned firms in the country were more likely to use the Internet than their male counterparts. Also, in comparison to their male counterparts, these firms were more likely to use websites to communicate with their clients. Generally, the usage of the Internet by businesses, regardless of the gender of the owners/managers, leads to better performance of firms (Clarke et al., 2015). Therefore, the paper analyzed whether the adoption of the Internet by firms owned/managed by females in India led to better performance. In order to measure the performance 
of these Indian female-owned firms, productivity and sales growth were analyzed. The empirical results indicated that the adoption of the Internet by these firms did not make them more or less likely to have higher productivity and/or deliver higher sales growth. These results indicate that, although the female-owned firms have adopted the Internet more extensively than their male counterparts, this did not necessarily get transmitted into greater productivity or sales growth. Thus, these firms were missing out on an important opportunity to have better performance in spite of more extensive Internet adoption.

There can be various explanations for these surprising results. One of the potential reasons can be the quality of employees. Firms having Internet access on their premises does not necessarily mean that employees of these firms have the necessary skills and/or the required training to use the technology for the benefit of the firms that can eventually increase sales or productivity; some studies indicate that this is a very likely reason in other countries (Colombo et al., 2013; Hashim, 2015). Further, the speed of the Internet connection also plays a decisive role in the level of increased productivity. The extant literature suggests that a basic broadband Internet connection does not have a positive impact on the performance of the firms, but a high speed broadband connection does (Bertschek, 2012; Grimes et al., 2012). Additionally, a time lag may exist in the adoption of Internet and its impact on productivity of firms (Susanto Basu \& Fernald, 2007). Finally, the adoption of the Internet by female-owned firms may lead to results in intangible forms such as increased customer service satisfaction and convenience (Brynjolfsson \& Hitt, 2000). If this is the case, some time may be needed to observe the effect of this increased customer satisfaction into higher sales and productivity.

It can be further argued that there may be economic reasons behind the results obtained in this paper. Part of the problem can be attributable to the fact that India has a cash-based economy. Additionally, it is a country where more than 70 percent of the economy belongs to the informal sector. This makes it impossible to keep track of various parties involved in business processes. To this end, the current Indian government has been undertaking bold economic reforms. One of the activities that the current Government has undertaken recently is to demonetize the economy and encourage people in the country to use either plastic money or mobile money (cell-phone-based monetary transactions). These reforms, although extremely painful in the beginning, especially for the poor in the country, have a tremendous potential to change the way businesses carry out their financial transactions and the way the economy functions. For example, if large parts of the economy carry out financial transactions using digital money, it will be treated as a formal 
economy. Also, this process can lead to the generation of electronic records of transactions and can thus attract taxes, thereby increasing the revenues of the government. Most importantly, businesses will have easy access to data bases on their clients. This set up will lead to enhanced repeat business, better products, and customer loyalty. In the long run, this process will result in increased sales growth, employment, and government revenues.

The current study has a few limitations. It only looked at female-owned firms in India. Because, no specific questions on the adoption of the Internet were asked in the data set from the year 2010, a comparative study vis-a-vis the year 2014 for adoption of the technology was not possible. The current study suggests many exciting avenues for future research. For example, the same kind of empirical analysis can be performed on other developing countries, such as Brazil, Mexico, and Turkey. Also, it will be interesting to determine why male-owned firms in India have a lower Internet adoption rate than their female counterparts and how this affects their productivity and sales.

\section{References}

Adam, S., Mulye, R., Deans, K. R., \& Palihawadana, D. (2002). E-marketing in perspective: A three country comparison of business use of the Internet. Marketing Intelligence \& Planning, 20(4), 243-251.

Adapa, S. (2008). Adoption of internet shopping: Cultural considerations in India and Australia. Journal of Internet Banking and Commerce, 13(2), 1-17.

Aterido, R., Beck, T., \& lacovone, L. (2011). Gender and finance in Sub-Saharan Africa: Are women disadvantaged? Policy Research Working Paper, No. 5571, Washington DC: The World Bank.

Aterido, R., \& Hallward-Driemeier, M. (2011). Whose business is it anyway? Small Business Economics, 37(4), 443-464.

Bardasi, E., Sabarwal, S., \& Terrell, K. (2011). How do female entrepreneurs perform? Evidence from three developing regions. Small Business Economics, 37(4), 417-441.

Basu, S., \& Fernald, J. (2007). Information and communications technology as a general-purpose technology: Evidence from US industry data. German Economic Review, 8(2), 146-173.

Basu, S., \& Fernald, J. (2007). Information and communication technology as a general purpose technology: Evidence from U.S. industry data. Federal Reserve Board of San Francisco Economic Review, 8(2), 146-173.

Bersnahan, T., F., \& Trajtenberg, M. (1995). General purpose technologies "engine of growth'?. Journal of Econometrics, 65(1), 83-108.

Bertschek, I. (2012). ICT, internet and worker productivity. In S. N. Durlauf \& L. E. Blume (Eds.), The New Palgrave Dictionary of Economics. Palgrave Macmillan. Online Edition. 
Brynjolfsson, E., \& Hitt, L.M. (2000). Beyond computation: Information technology, organizational transformation and business performance. The Journal of Economic Perspectives, 14(4), 23-48.

Clarke, G. R., Qiang, C. Z., \& Xu, L. C. (2015). The Internet as a general-purpose technology: Firm-level evidence from around the world. Economics Letters, 135, 24-27.

Colombo, M. G., Croce, A., \& Grilli, L. (2013). ICT services and small businesses' productivity gains: An analysis of the adoption of broadband Internet technology. Information Economics and Policy, 25(3), 171-189.

Dasgupta, S., Agarwal, D., Ioannidis, A., \& Gopalakrishnan, S. (1999). Determinants of information technology adoption: An extension of existing models to firms in a developing country. Journal of Global Information Management (JGIM), 7(3), 30-40.

Dholakia, R. R., \& Kshetri, N. (2004). Factors impacting the adoption of the Internet among SMEs. Small Business Economics, 23(4), 311-322.

Grimes, A., Ren, C., \& Stevens, P. (2012). The need for speed: Impacts of internet connectivity on firm productivity. Journal of Productivity Analysis, 37(2), 187-201.

Hansen, H., \& Rand, J. (2014). The myth of female credit discrimination in African manufacturing. Journal of Development Studies, 50(1), 81-96.

Hashim, J. (2015). Information communication technology (ICT) adoption among SME owners in Malaysia. International Journal of Business and Information, 2(2).

Kumar Sharma, S., \& Madhumohan Govindaluri, S. (2014). Internet banking adoption in India: Structural equation modeling approach. Journal of Indian Business Research, 6(2), 155-169.

Levy, M., \& Powell, P. (2003). Exploring SME internet adoption: towards a contingent model. Electronic Markets, 13(2), 173-181.

Malhotra, P., \& Singh, B. (2007). Determinants of internet banking adoption by banks in India. Internet Research, 17(3), 323-339.

Mehrtens, J., Cragg, P. B., \& Mills, A.M. (2001). A model of Internet adoption by SMEs. Information \& Management, 39(3), 165-176.

Oliveira, T., \& Martins, M. F. (2010). Information technology adoption models at firm level: review of literature. Paper presented at the European Conference on Information Management and Evaluation.

Poon, S., \& Swatman, P. M. (1997). Small business use of the Internet: Findings from Australian case studies. International Marketing Review, 14(5), 385402.

Porter, M. E. (2001). Internet strategy. Harvard Business Review, 79(3), 62-78. Rangaswamy, N., \& Cutrell, E. (2012). Anthropology, development and ICTs: slums, youth and the mobile internet in urban India. Paper presented at the Proceedings of the Fifth International Conference on Information and Communication Technologies and Development.

Raven, P. V., Huang, X., \& Kim, B. B. (2009). E-Business in developing countries: A comparison of China and India. In I. Lee (Ed.), Selected Readings on 
Information Technology and Business Systems Management (pp. 385403). IGI Global Hershey, PA.

Riquelme, H. (2002). Commercial Internet adoption in China: Comparing the experience of small, medium and large businesses. Internet Research, $12(3), 276-286$.

Röller, L.-H., \& Waverman, L. (2001). Telecommunications infrastructure and economic development: A simultaneous approach. American Economic Review, 91(4),909-923.

Roy, S. K., Kesharwani, A., \& Singh Bisht, S. (2012). The impact of trust and perceived risk on internet banking adoption in India: An extension of technology acceptance model. International Journal of Bank Marketing, 30(4), 303-322.

Shore, B. (1998). IT Strategy: The challenge of over-regulation, culture, and large-scale collaborations. Journal of Global Information Technology Management, 1(1), 1-4.

Sin Tan, K., Choy Chong, S., Lin, B., \& Cyril Eze, U. (2010). Internet-based ICT adoption among SMEs: Demographic versus benefits, barriers, and adoption intention. Journal of Enterprise Information Management, 23(1), 27-55.

Tarafdar, M., \& Vaidya, S. D. (2006). Challenges in the adoption of E-Commerce technologies in India: The role of organizational factors. International Journal of Information Management, 26(6), 428-441.

Teo, T. S., \& Pian, Y. (2003). A contingency perspective on Internet adoption and competitive advantage. European Journal of Information Systems, 12(2), 78-92.

Teo, T. S., Tan, M., \& Buk, W. K. (1997). A contingency model of Internet adoption in Singapore. International Journal of Electronic Commerce, 2(2), 95-118.

The World Bank. (2014). Enterprise Surveys Program.

The World Bank. (2016a). Doing Business Report.

The World Bank. (2016b). World Development Indicators.

Walczuch, R., Van Braven, G., \& Lundgren, H. (2000). Internet adoption barriers for small firms in the Netherlands. European Management Journal, 18(5), 561-572.

\footnotetext{
Abstract (in Polish)

Internet całkowicie przekształcił nasze życie indywidualnie na wiele sposobów, poczq̨wszy od sposobów komunikowania się poprzez sposób, w jaki towarzyszy nam przy robieniu zakupów i podróżach. Firmy nie sq wyjq̨tkiem od tej przesłanki. W artykule tym analizujemy wykorzystanie Internetu przez kobiety będqce właścicielkami firm w Indiach. Wykorzystujemy zestaw danych Programu ankiety dla przedsiębiorstw Banku Światowego na rok 2014, aby zbadać wykorzystanie Internetu przez ponad 10000 firm w kraju. Po sprawdzeniu dużej liczby charakterystyk na poziomie firmy, uzyskane wyniki empiryczne wskazuja, że kobiety będq̨e właścicielkami firm
} 
częściej korzystajq z Internetu niż ich partnerzy płci męskiej. Jednak kolejna analiza empiryczna wskazuje, że bardziej intensywne wprowadzanie Internetu przez te kobiety, niekoniecznie przekłada się na lepsze wyniki. Wykorzytsanie Internetu nie powoduje, że przedsiębiorstwa będq̨e własnościq kobiet majq mniej lub bardziej prawdopodobny wzrost wydajności i wzrostu sprzedaży w przeciwieństwie do ich partnerów. Słowa kluczowe: Internet; kobiety; produktywność; wzrost sprzedaży w Indiach.

\section{Bibliographical note}

Aparna Gosavi, Ph.D., is an assistant professor of finance at Winston-Salem State University, University of North Carolina System, North Carolina, USA. Her main research areas include corporate finance, banking and finance, survival of firms in pre- and post 2008 financial crises, and mobile money. 